\title{
Ergonomics aspect review: Effectiveness of information-based technology display at the Mpu Purwa Museum in Malang
}

\author{
T.I.W. Primadani, I.A. Agustina \& I.B.A. Wijaya \\ Bina Nusantara University, Malang, Indonesia
}

\begin{abstract}
In Indonesia, to support their exhibition, some museums have been already been applying multimedia and interactive technologies in their presentations, including the Mpu Purwa Museum in Malang. The purpose of this study is to find the ease of the ergonomic aspect so that the stored information can be easily obtained by visitors and to determine the effectiveness of the QR code label at the Mpu Purwa Museum in terms of ergonomics. The problem is the application of the QR code as part of a display object in a museum exhibition in Indonesia is still relatively new, so its effectiveness needs to be reviewed. The method used in this research is qualitative, with data collection in field studies, visitor interviews, and literature studies. The results of this study conclude that the ergonomics of anthropometry, display location, lighting, and circulation areas must adapt to each other with the type of technology-based media used in the museum.
\end{abstract}

Keywords: ergonomic, QR code, display, technology, museum

\section{INTRODUCTION}

One thing that supports a visitor's multidimension experience in museum exhibitions is the concept of audience participation. In participatory-concept museums, the two-way interpersonal communication can be achieved by interactive exhibits through various media such as audiovisual, touchscreen, and multimedia (Wulandari 2014). The format of delivering information in a different packaged museum will be easier for visitors to remember than passive writing without meaningful interaction, such as typographic presentations on walls or information that can explore through gadgets (Palmyre Pierroux 2019).

Technology developments, especially smartphones, affect emerging behavior (Weilenmann et al. 2013). With the increasing use of smartphones and sensory system technology developments, public spaces such as libraries or museums now have the opportunity to enhance their visitor experience and further achieve their institutional goals (Mar Perez-Sanagustín 2016). The strategy of using technology, such as mobile applications, touchscreens, and websites, is considered one of the most effective design systems for presentation methods in museums and learning environments (Al-Hajji 2017). Technology in the museum also uses existing historical collection objects, for example, to explain and describe the collection's background story. By utilizing technology, the museum's display collections are expected to provide a new experience in interacting with objects that are in the museum display.

A QR code consists of a black box module, which is a code that can be read by a scanner or a gadget camera that has been facilitated by this QR code reader application, and that code links with the digital information storage of the related object on the internet. By that explanation, it can be seen that QR code technology allows visitors to interact with collections in the museum by utilizing their smartphone. According to previous research, a QR code is an option for cost-effectiveness in museums and has been applied by several museums to guide visitors and contains information that supports exhibitions or libraries (Schultz 2013). 


\subsection{Ergonomic display in museum}

Ergonomics is a scientific discipline that is concerned with understanding the interactions between humans and other elements of a system, providing theoretical principles, data, and methods for designing how to optimize human well-being and overall system performance (Erminia Attaianese 2012). The goal of the ergonomic design of the museum environment is to create prevailing ambient conditions that are comfortable and acceptable accommodations of activity performance or visitor health (Stanton 2005). The aspects of the physical environment in the museum that can affect the effectiveness of information presented are noise, lighting, ergonomics of the eye line (anthropometry), the connectedness of the content and objects on display, visual elements, and their location to the visitor's circulation flow (Screven 1992; Wulandari et al. 2017). Effective layout and display designs are designed to engage visitors for self-education on a subject and to inspire the visitors to learn more (Wolfgang Leister 2016). If there is any display design's fault and improper arrangement both visually or physically, that means the collection will potentially be overlooked by visitors.

Labels on collection displays also play an important role in providing information to visitors. Information labels are important to provide a deep understanding of a display object in a museum (Wulandari et al. 2017). Labels refer to all types of media - print, audio, graphics, and presentation formats - used to help visitors interpret and connecting with exhibition content, have an emotional impact, or to motivate visitors to get to know more (Screven 1992). The presentation aspect of label format includes all type of media used such as interactive, sound, image, and video.

In order to be easily read by visitors, object information labels need to be designed in accordance with human ergonomic standards by paying attention to attractive visualizations and placing them according to the normal human eye line (Wulandari et al. 2017). Several techniques have been used in previous research to display effective information designs in the form of graphics, sculptures, boards, or other information products in museums by following UX design principles (Al-Hajji 2017). Principles of UX Design are easy to use, to find the function, and to understand; users do not have to get help to do the task; visual focus, direction are clear; and users can perform their task efficiently and correctly, works for the user (Rosenzweig 2015).

Another supporting factor for the ergonomics of the interior environment is lighting. Lighting has an important role in the exhibition space, both for the conservation of collections and visitors (Hunt 2009). With an appropriate light, exhibition organizers are present with an influential tool that enables the definition of the atmosphere for viewing art, establishes a sense of drama to support its reception, and generally contributes to the success of the exhibition (Schielke 2019). The lighting intensity is very important for visitors to be able to easily observe the collection and read the label information clearly (Wulandari et al. 2017).

\subsection{Objectives}

In this study, we will discuss the effectiveness of a $\mathrm{QR}$ code as a label for statues collection at the Mpu Purwa Museum in terms of the ergonomics placement. A QR code label contains descriptions and explanations of the statue collection in Bahasa and English in the Mpu Purwa Museum. The Mpu Purwa Museum is a public museum located on Kota Malang, East Java. Most of the Mpu Purwa Museum collections are statues and inscriptions from the Mpu Sindok period to the Majapahit Kingdom (year 929-947 AC).

Ergonomic problems in placing QR codes as information labels for collections in museums that will be discussed in this paper are lighting and anthropometry related to the placement of QR codes. Based on visitor interviews and field observations, the problem found in implementing QR codes as collection information is that not all of them can be seen by visitors and require more effort to aim the smartphone camera at the QR code. Other problems are the material selection, QR code image placement, and lights position that cause a very bright reflection on a QR code.

\section{METHODOLOGY}

The research method used in this research is the qualitative method by conducting literature studies, field studies, and interviews. Studies conducted to search for reference data and analyzing the 


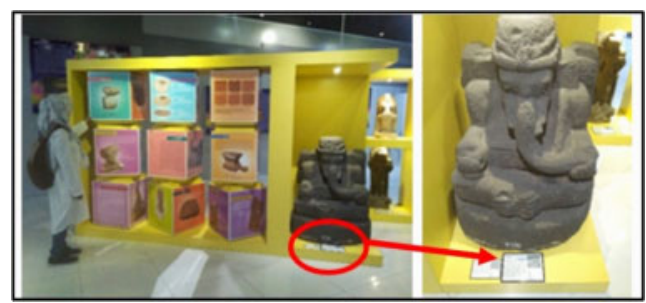

Figure 1. QR code placement case A.

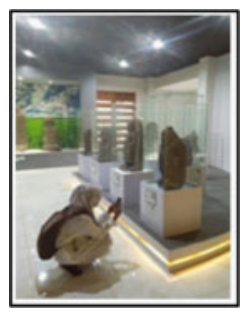

Figure 2. QR code placement case B.

Table 1. QR Code label location identification.

\begin{tabular}{|c|c|c|c|c|c|}
\hline \multirow{3}{*}{$\begin{array}{l}\text { Case } \\
\text { Study }\end{array}$} & \multirow{3}{*}{$\begin{array}{l}\text { QR Code } \\
\text { Location }\end{array}$} & \multirow{3}{*}{$\begin{array}{l}\text { Circulation } \\
\text { Dimension }\end{array}$} & \multirow{2}{*}{\multicolumn{2}{|c|}{$\begin{array}{c}\text { Standart Dimension } \\
\text { (Panero and Zelnik 2003) }\end{array}$}} & \multirow[t]{3}{*}{ Effort } \\
\hline & & & & & \\
\hline & & & $\begin{array}{l}\text { Line-of-sight place- } \\
\text { ment }\end{array}$ & Minimum circulation area & \\
\hline $\begin{array}{l}\text { A - } \\
\text { Figure 1 }\end{array}$ & $\begin{array}{l}10 \mathrm{~cm} \text { from the } \\
\text { floor }\end{array}$ & $200 \mathrm{~cm}$ & $\begin{array}{l}107-170 \mathrm{~cm} \text { from } \\
\text { the floor }\end{array}$ & $\begin{array}{l}167.6 \mathrm{~cm} \\
\text { (accommodate two people } \\
\text { viewed the display and cir- } \\
\text { culation for one person.) }\end{array}$ & $\begin{array}{l}\text { Visitors must bow their heads or } \\
\text { their bodies to read labels or scan } \\
\text { QR codes with their smartphones. }\end{array}$ \\
\hline $\begin{array}{l}\text { B - } \\
\text { Figure } 2\end{array}$ & $\begin{array}{l}50 \mathrm{~cm} \text { from the } \\
\text { floor }\end{array}$ & $140 \mathrm{~cm}$ & & & $\begin{array}{l}\text { Visitors must squat down to read } \\
\text { labels or scan QR codes with their } \\
\text { smartphones. }\end{array}$ \\
\hline
\end{tabular}

interior aspects that affect the display of museum collections, lighting, sirculation and ergonomics anthropometric display design technology based on museum collections. Meanwhile, field studies were conducted to determine the ergonomic aspects of anthropometric display arrangement equipped with QR codes and the size of the circulation area. Interviews were conducted with managers and visitors about the purpose QR code application and comfort when reading QR code in the museum.

\section{RESULT AND DISCUSSION}

Based on field studies in the statues collection area, there is a QR code label on each collectable. QR code labels are placed near the object and located on the front of the display case. Placement of the labels next to the object makes it easier for visitors to see the object and read the label at the same time (Bitgood 2002). However, in case study A (Figure 1), the label was placed at a height of $10 \mathrm{~cm}$ from the floor. In case B (Figure 2), the label was placed on the front of the display case at a height of $50 \mathrm{~cm}$ from the floor.

The black QR code is printed on a white paper measuring $10 \times 15 \mathrm{~cm}$ and laminated by plastic. Label not only contains a QR code but contains collection name and description in Bahasa and 
English in terms of visibility, the label applies a ground-figure contrast. Not only is it easier to attract attention with a ground-figure contrast, but it is easier to read text when the letters and background have high contrast (Bitgood 2002). Labels that are located in line of sight will be easily detected and legible, however, the QR code label on the study object (Figures 1 and ;) is located far from the eye line area in a normal standing position and using small font size results, cause information on the label is not easy for visitors to read. Labels that are not in the eye line area will affect the effectiveness because it will tend to be overlooked and unreadable by visitors. Visitors have to spend extra effort by squatting or bending in the attempt to read the QR code label. The extra effort is one of the distractions that affect motivation and focus the attention of visitors (Bitgood 2002).

Based on field studies, represented by cases A (Figure 1) and B (Figure 2), the circulation width inside the museum is quite narrow to accommodate the activities of a squatting visitor while aiming smartphone cameras at the QR code and tend to disturb other visitor circulation areas. The circulation width area in the museum does not yet meet the minimum required standard for circulation width according to anthropometric ergonomics (explanation in Table 1).

Placement of objects and the space provided in the museum should pay attention to the comfort of visitor's activity. Object and space can become the focus of attention, facilitate or encourage the movement of visitors, provide a rhythm or balance, and can improve visual and physical abilities to enjoy the collection in the museum (Swathi Matta Reddy 2012). If there is one that doesn't meet the standard, the activity comfortability will be disturbed. Squatting and bowing while aiming the cellphone camera at the QR code will take up a wider space, so it can interfere others circulation area, especially if the museum has a lot of visitors. Circulation disturbances can also cause crowds, thus disturb visitors' comfort while observing collections in museums or reading the existing information. This disturbance can cause the object around it to be less notified by visitors.

In arranging and placing technology to support historical collections, several things need to be considered in order to be effective, one of which is the interior environmental conditions. Physical aspects of the environment such as visibility generated from lighting effects, visual barriers, and glare will affect the appearance of the display so that it also affects the attention of visitors (Schielke 2019). Based on the existing, the lighting used at the Mpu Purwa Museum is $25 \%$ natural lighting and $75 \%$ artificial lighting. Artificial lighting is used as a general light and decorative light to expose the collection. There is no special lighting that exposes QR code labels, so the lighting takes advantage of general light or spotlight that leads to the display object.

QR code labels must be well lit. Based on research on the mobile phone audiovisual guide tour at Ueno Zoological Gardens and the National Science Museum in Tokyo, visitors find it difficult to scan QR codes in a dark gallery area (Sakamoto \& Sakamoto 2007). However, lighting that is too bright must also be considered, because it can cause a glare effect both in camera phone and visitor's eye. If there is glare or too much reflective light, guests may experience discomfort while interacting in the museum, and their experience will be greatly altered (Hunt 2009). Based on a case study at the Mpu Purwa Museum, there are several QR codes that reflect light from a spotlight that illuminates the collection object, so visitors must find the right position so that the scanned QR code does not have a white spot reflected by the light.

The problem with the appearance of a white spot is that the QR code label has a shiny plastic material facing the spotlight so that a bright light reflection occurs. This condition can be overcome by moving it to a part that is not directly facing the direction of the light, moving the location of the spotlight or replacing the QR code label material with a non-reflective material. From this condition, it can be concluded that physical environmental aspects such as lighting also play an important role in influencing the effectiveness of the information on labels, even though the presentation and type of labels displayed are based on the latest technology. Determination of the placement and type of lamp used has a correlation with other elements in an interior space (Swathi Matta Reddy 2012). The placement of lights, QR code labels, and materials used must be considered so that the information presented can be easily accessed by museum visitors. 


\section{CONCLUSION}

The advantage of using a label that uses a QR code at the Mpu Purwa Museum provides a new experience for visitors to use a smartphone to get information about the object collections in the museum. Tshe drawback is the location QR code label placement that does not comply with ergonomic standards anthropometry, so the label of QR code placement on at the Mpu Purwa Museum is still not effective. To maximize the benefit by QR code label, the label should be moved to a place that meets the anthropometric-ergonomic standards of human activity and aligns it with the lighting placement in the interior of the Mpu Purwa Museum. Based on the ergonomic analysis of the QR code label at the Mpu Purwa Museum which was described above, it can be concluded that the physical condition of the environment must be reconsidered and redesigned in order to maximize the benefits of using digital technology to increase visitor engagement with museum collection objects. Physical environmental factors such as ergonomics of object's placement, lighting, and area of circulation must be adapted to the type of technology-based information media used in the museum. If visitors can take full advantage of it, it is hoped that the information conveyed by utilizing digital-based technology can be well received by visitors.

\section{ACKNOWLEDGMENTS}

This paper is part of the results of a beginner lecturer research (PDP) scheme, a research grant from Ministry of Research and Technology Indonesia (RISTEKDIKTI).

\section{REFERENCES}

Al-Hajji, Z. 2017. Applying user experience (UX) design in interior space for art, science museums, and learning environments. [Online] Available at: https://commons.emich.edu/theses/791/ [Accessed October 5, 2020].

Bitgood, S. C. 2002. Environmental Psychology in Museums, Zoos, and Other Exhibition Centers. In: Handbook of Environmental Psychology. New York: John Wiley \& Sons, Inc, pp. 461-480.

Erminia Attaianese, G. D. 2012. Human factors and ergonomic principles in building design for life and work activities: an applied methodology. Theoretical Issues in Ergonomics Science, 13(2):187-202.

Hunt, E. G. 2009. Study of Museum Lighting and Design. [Online] Available at: https://digital.library.txstate. edu/handle/10877/3203 [Accessed October 5, 2020].

Julius Panero, M. Z. 2003. Dimensi Manusia dan Ruang Interior. 1st ed. Jakarta: Erlangga.

Mar Perez-Sanagustín, D. P. R. V. G. G.-G. 2016. Using QR codes to increase user engagement in museum-like spaces. Computers in Human Behavior, 60:73.

Palmyre Pierroux, A. Q. 2019. Wall texts in collection exhibitions: Bastions of enlightenment and interfaces interfaces for experience. Nordisk Museology, 1:39-50. [Online]

Available at: https://www.duo.uio.no/handle/10852/75254 [Accessed October 2020].

Panero, J. and Zelnik, M. 2003. Dimensi Manusia dan Ruang Interior. 1st ed. Jakarta: Erlangga.

Rosenzweig, E. 2015. Successful User Experience: Strategies and Roadmaps. MA-USA: Morgan KaufmannElsevier.

Safavi, S. 2013. Eastern Mediterranean University Institutional Repository: Effects of Design Principles on Visitors 'Perception in Museum Spaces. [Online] Available at: http://hdl.handle.net/11129/3495 [Accessed October 10, 2020].

Sakamoto, H. and Sakamoto, K. 2007. Using a Mobile Phone Tour to Visit the Ueno Zoological Gardens and the National Science Museum in Tokyo, Japan. Journal of Museum Education, 32(1):35-45.

Salim, P. 2018. Persepsi Kualitas Ruang Pamer Museum Seni: Sebuah Studi Observasi. NARADA, Jurnal Desain \& Seni, FDSK - UMB 5(2):23-32.

Schielke, T. 2019. Interpreting Art with Light: Museum Lighting between Objectivity and Hyperrealism. LEUKOS : The Journal of the Illuminating Engineering Society.

Schultz, M. K. 2013. A case study on the appropriateness of using quick response (QR) codes in libraries and museums. Library \& Information Science Research, http://dx.doi.org/10.1016/j.lisr.2013.03.002.

Screven, C. G. 1992. Motivating Visitors to Read Labels. ILVS, 2(2). 
Stanton, N. A. 2005. Human Factors and Ergonomics Methods. In: N. A. Stanton, ed. Handbook of Human Factors and Ergonomics Methods. Neville: CRC Press, pp. 1-1-1-9.

Swathi Matta Reddy, D. C. S. K. 2012. Emotion and interior space design: an ergonomic perspective. s.1., IOS Press.

Weilenmann, A., Hillman, T,. and Jungselius, B. 2013. Instagram at the Museum: Communicating the Museum Experience through Social Photo Sharing. Paris, ACM Press.

Wolfgang Leister, I. T. T. S. G. J. A. L. M. d. B., 2016. Assessing Visitor Engagement in Science Centres and Museums. International Journal on Advances in Life Sciences, 8(1 \& 2):50-64.

Wulandari, A. A. 2014. Dasar-dasar Perencanaan Interior Museum. Humaniora 5(1):246-257.

Wulandari, A. A. A., Fajarwati, A. A. S., and Latif, F. 2017. The Relationship of Exhibition Space Design and The Success of Delivering Messages To Museum Visitors In Jakarta. Humaniora 8(3):219. 


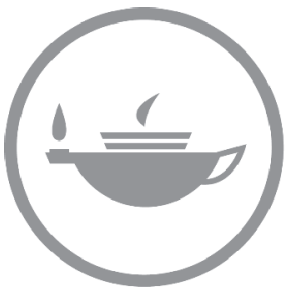

Taylor \& Francis Taylor \& Francis Group

http://taylorandfrancis.com 